XXXII.-Descriptions of some new Species of Heterocera. By Herbert Druce, F.L.S. \&c.

\title{
Fam. ÆEgeriidæ.
}

Sciapteron Meeki, sp. n.

Male.-Primaries bright purplish blue, the costal and outer margins edged with black, the underside almost brighter than the upperside: secondaries hyaline, with a large metallicblue marking from the base extending to the end of the cell and below the cell nearly to the outer margin; the outer and inner margin edged with black; the fringe of both wings black. The antennæ, head, thorax, abdomen, and legs black; the collar and palpi yellow ; anal tuft black.

Expanse $1 \frac{1}{2}$ inch.

Hab. Trobriand Islands, Kiriwini (A. S. Meek, Mus. Druce).

This species is allied to S. pulchripennis, Walk., from which it is at once distinguished by its much brighter colour, narrower black margins to the primaries, and several minor differences.

Fam. Syntomidæ.

Pseudosphenoptera triangulifera, sp. n.

Male.-Primaries black, shot with bright metallic green from the base to beyond the middle; a narrow hyaline streak at the base on the costal margin, below which is a round hyaline spot; the fringe black : secondaries deep black, with a small hyaline spot close to the base. On the underside both wings shot with dark blue at the base. Antennæ black; the head, thorax, and abdomen black, thickly irrorated with metallic-blue scales; abdomen with two white spots at the base and a row of white spots on each side; legs black, tipped with white.

Expanse $1 \frac{1}{4}$ inch.

Hab. Amazons (Mus. Druce).

\section{Desmidocnemis thyria, sp. $\mathrm{n}$.}

Male.-Primaries and secondaries yellowish hyaline, all the veins black; primaries with the costal, outer, and inner margins narrowly edged with black : secondaries black at the 
apex and partly along the outer margin. 'The antennæ, head, thorax, and legs black; the abdomen greenish black.

Expanse 1 $\frac{1}{10}$ inch.

Hab. Ecuador, Balsapamba (Mus. Druce).

\section{Chloropsinus nox, sp. n.}

Female-Primaries and secondaries uniformly dull brownish black; primaries with two small metallic-green spots close to the base; the fringe of both wings black. Underside very similar to the upperside, but the primaries with a bluishgrey streak from the base to the end of the cell. The antennæ black, tipped with white; head black, spotted with metallic green; thorax, abdomen, and legs brownish black, abdomen with a metallic-green spot at the base.

Expanse $1 \frac{1}{2}$ inch.

Hab. Ecuador, St. Lucia (Mus. Druce).

\section{Agyrta monoplaga, sp. n.}

Male.-Primaries black, shot with blue at the base and along the inner margin; a wide whitish hyaline band crosses the wing about the middle from the costal margin almost to the apex: secondaries black, shot with bright blue at the base and along the inner margin. Antennæ black; the head red; thorax and abdomen dark bright blue; front of the head and underside of thorax white; the legs bluish black.

Expanse $1 \frac{4}{1 \sigma}$ inch.

Hab. Ecuador, Balsapamba (Mus. Druce).

\section{Pseudaclytia umbrica, sp. n.}

Male-Primaries pale brown, darkest at the base and partly along the costal margin: secondaries darker brown except along the costal margin. The underside of both wings very pale brown. The head, antennæ, thorax, and base of abdomen pale brown, the abdomen black above, the underside and the legs brownish white, the sides of the abdomen and anal tuft yellow.

Expanse $1 \frac{1}{10}$ inch.

Hab. Brazil, Cabo (Forbes, Mus. Druce).

Fam. Laparidæ.

Lymantria mosera, sp. n.

Male.-Primaries pale brown, crossed about the middle by a wide white band, which becomes quite narrow near the 
inner margin; the veins crossing the white band are pale brown, the fringe pale brown: secondaries pale yellow, slightly darker along the inner margin. The head and thorax pale brown; abdomen darker yellow than the secondaries; antennæ black.

Expanse $1 \frac{1}{2}$ inch.

Hab. East Africa, Delagoa Bay (Mus. Druce).

Both sexes of this species are in the National Collection; the female is considerably larger than the male, but in other respects it is very similar.

\section{Lymantria Thomsoni, sp. n.}

Female.-Primaries pale brownish fawn-colour, with a large silvery-white spot at the end of the cell, beyond which are several small silvery-white dots; the fringe pale brown: secondaries semihyaline brownish white. The head, thorax, and abdomen pale brownish fawn-colour.

Expanse $2 \frac{1}{4}$ inches.

Hab. West Africa, Mongo-ma-Lobah (Mus. Druce).

\section{Lymantria hera, sp. n.}

Male.-Primaries pale brown, crossed from the costal to the inner margin by zigzag black lines; a rather large brownish-black spot near the anal angle and one above on the outer margin; the fringe alternately black and pale brown : secondaries cream-colour, with the fringe alternately black and cream-colour. Antennæ black; the head, thorax, and abdomen brown.-Female very similar to the male, but with the secondaries pale brown.

Expanse, ơ $1 \frac{1}{4}$, o $1 \frac{1}{2}$ inch.

Hab. East Africa, Dar-es-Salaam (Mus. Druce).

\section{Ecura Whitei, sp. n.}

Female.-Primaries brown, with a large greyish-white spot near the apex, and the inner margin from the base to the anal angle broadly bordered with greyish white, dentated on the inner side: secondaries dull brown; the fringes of both wings brown. The head, antennæ, and collar brown; the thorax and tegulæ greyish white; the abdomen and legs brown.

Expanse $1 \frac{1}{2}$ inch.

Hab. West Africa, Old Calabar (White, Mus. Druce). This species is allied to O. Goodii, Holland. 


\section{Ecura pytna, sp. n.}

Male.-Primaries brownish fawn-colour, darker along the costal margin ; a small black streak close to the base; a large greyish-white marking near the apex, below which are two or three brownish-black markings; the fringe alternately light and dark brown: secondaries pale greyish brown; with two darker brown spots on the outer margin; the fringe pale greyish white. Antennæ black; the head, thorax, and abdomen dark greyish brown.

Expanse $1 \frac{1}{2}$ inch.

Hab. West Africa, Gambia (Mus. Druce).

\section{Fam. Notodontidæ.}

\section{Notodonta (?) phronima, sp. n.}

Male.-Primaries semihyaline greyish white, darkest at the base and along the costal margin ; a faint black streak at the end of the cell; a wide, red, curved, elongated spot about the middle of the inner margin: secondaries hyaline white, shaded with pinkish fawn-colour along the inner margin. Underside of both wings white; antennæ pale brown; the head and thorax pale brown, thickly clothed with reddish hairs; abdomen yellowish brown; legs white.

Expanse $2 \frac{1}{4}$ inches.

Hab. South Brazil (Mus. Druce).

Very distinct from any other species known to me, and will probably require to be placed in a new genus.

\section{Fam. Arctiidæ.}

\section{Catarctia unicolor, sp. n.}

Female.-Primaries and secondaries uniformly chestnutreddish brown. The head, antennæ, and thorax of the same colour; abdomen yellowish brown, with a double row of black spots on the upperside.

Expanse $2 \frac{1}{4}$ inches.

Hab. West Africa, Mongo-ma-Lobah (Mus. Druce).

\section{Spilarctia puella, sp. n.}

Male.-Primaries white, the veins all black: secondaries white, shaded with yellow along the inner margin ; the fringe of both wings white. Underside as above, but with the costal margins of both wings yellow. The head and thorax 
white; the collar yellow; antennæ black; abdomen deep chrome-yellow, with a row of black spots down the middle.

Expanse $1 \frac{3}{4}$ inch.

Hab. South-east Africa, Pondoland (Mus. Druce).

\section{Spilarctia vittata, sp. n.}

Male-Drimaries very pale brownish white, with three square-shaped brown spots along the costal margin-the first near the base, the second about the end of the cell, the third near the apex; the inner and outer margins thickly irrorated with small brown scales. The underside with the brown costal marks as above; the wing shaded with pink from the base to beyond the middle. Secondaries white, with the inner margin shaded with pink; a small black spot at the end of the cell. The head, thorax, and base of the abdomen brownish white, the abdomen pink above, brownish white on the underside; the antennæ and legs pink.

Expanse $1 \frac{3}{4}$ inch.

Hab. West Africa, Mongo-ma-Lobah (Mus. Druce).

\section{Spilarctia radiosa, sp. n.}

Female.-Primaries cream-colour, crossed by two brown $>$-shaped lines-the first near the base, the second beyond the middle, extending from the costal margin to the end of the cell, then to the outer margin; several dark brown spots near the apex and a marginal row of brown spots extending from the apex to the anal angle: secondaries nearly white, with a small black spot at the end of the cell; two brown spots close to the anal angle and one near the apex, and a marginal row of minute brown dots at the apex, extending partly round the outer margin. Underside of both wings very similar to the upperside. Antennæ black; head very pale yellow; thorax cream-colour, spotted with black; the abdomen yellow, with a row of black spots on each side, the underside of the abdomen brownish white.

Expanse 3 inches.

Hab. West Africa, Calabar (Mus. Druce).

\section{Spilarctia rava, sp. $\mathrm{n}$.}

Female.-Primaries pale brownish fawn-colour, thickly irrorated with darker brown scales, which form two very indistinct bands crossing the wing from the costal to the inner margin: secondaries white, with a large black spot at the end of the cell, two at the anal angle, and one close to the apex. 
The head and thorax pale brownish fawn-colour, spotted with black; the abdomen yellow, with three bands of black spots, one down the middle and one on each side; the underside of the abdomen and legs brown; antennæ black.

Expanse $2 \frac{1}{4}$ inches.

Hab. West Africa, Gambia (Mus. Druce).

$$
\text { Idalus (?) evippus, sp. } \mathrm{n} \text {. }
$$

Male and female.-Primaries pale pea-green, the costal and outer margins edged with yellow, the fringe yellow: secondaries semihyaline, considerably paler than the primaries, the fringe very pale yellow. The head, thorax, and abdomen pea-green; antennæ black; the front of the head, underside of the thorax, and the legs yellow.

Expanse, $\sigma^{\pi}$ o, $1 \frac{1}{4}$ inch.

Hab. Bolivia (Mus. Druce).

\section{Idalus leos, sp. n.}

Primaries pale citron-yellow, crossed near the base by a faint zigzag reddish-brown line and beyond the middle by a straight reddish-brown line that extends from the apex to the middle of the inner margin; a round brown spot at the end of the cell ; the fringe yellow : secondaries cream-colour ; the head, antennæ, thorax, and abdomen yellow; the anal tuft pale brown.

Expanse $1 \frac{3}{10}$ inch.

Hab. Ecuador, Sarayacu (Mus. Druce).

\section{Euchoetes (?) lucida, sp. n.}

Male.-Primaries yellow, darkest at the base and along the costal margin; a small black spot at the end of the cell; the fringe yellow: secondaries cream-colour. The head, thorax, and abdomen chrome-yellow, the abdomen spotted with black down the middle; antennæ black.-Female the same as the male, but darker in colour.

Expanse $1 \frac{1}{4}$ inch.

Hab. East Africa, Dar-es-Salaam (Mus. Druce).

Fam. Lithosiidæ.

Darantasia Goldiei, sp. n.

Male.-Primaries glossy purple-black, the base, apex, and a band near the apex chrome-yellow: secondaries chromeyellow, broadly bordered with black. The head, antennæ, 
thorax, and leg; chrome-yellow; ablomen purple-black; the anus chrome-yellow.

Expanse 1 inch.

Hab. New Guinea, Port Moresby (Mus. Druce).

\section{Darantasia ccerulescens, sp. $\mathrm{n}$.}

Male.-Primaries bright glossy blue-black, the base and a rather wide band beyond the cell chrome-yellow; the fringe black : secondaries black, with a large central, round, chromeyellow spot. The head, thorax, and anal segments of the abdomen chrome-yellow; the antennæ black, tipped with yellow; the abdomen black.

Expanse $1 \frac{1}{4}$ inch.

Hab. Ferguson Island (Mus. Druce).

Fam. Melameridæ.

Mennis striata, sp. n.

Male.-Primaries chrome-yellow, the apex broadly black, streaked with yellow; a band of four black spots cross the wing about the middle from the costal to the inner margin: secondaries chrome-yellow, the apex and outer margin spotted with black. The head and antennæ black, the front of the head and collar white; thorax chrome-yellow; abdomen black, banded with white ; legs black.

Expanse 1 inch.

Hab. Ecuador, Angamarca (Mus. Druce).

\section{Mennis amica, sp. n.}

Male.-Primaries semihyaline yellow, the apex black, enclosing a rather large oval-shaped white spot, below which are two white streaks: secondaries semihyaline yellow, narrowly edged with black from the apex to the anal angle. The head, antennæ, and palpi black; the thorax, abdomen, and legs yellow.

Expanse 1 inch.

Hab. Ecuador, Sarayacu (Mus. Druce).

\section{Ephialtias batifica, sp. n.}

Primaries black, shot with rich dark blue to beyond the middle; a narrow pale yellow band crosses the wing beyond the cell from the costal margin to the anal angle; the fringe black: secondaries dark glossy blue, the apex and outer margin edged with black. The head, antennæ, and thorax 
black; abdomen and legs glossy blue; the underside of the head and front of the thorax yellow.

Expanse 2 inches.

Hab. Ecuador, Angamarca (Mus. Druce).

\section{Devara pallida, sp. n.}

Male.-Primaries blackish brown, the veins all black; an elongated spot at the end of the cell and a wide streak below the cell from the base almost to the anal angle orange-yellow : secondaries orange-yellow, broadly bordered with black, the veins black. The head, antennæ, thorax, abdomen, and legs black.

Expanse $1 \frac{1}{2}$ inch.

Hab. Bolivia (Mus. Druce).

\section{Fam. Dioptidæ.}

Neolaurona citrina, sp. n.

Primaries very similar to $N$. ovia, but with all the markings near the base and the first band crossing the wing orangeyellow instead of white: secondaries orange-yellow, broadly bordered with black. The head, antennæ, thorax, and abdomen black; underside of the abdomen greyish white.

Expanse 2 inches.

Hab. Upper Amazons (Mus. Druce).

\section{Stenele catax, sp. n.}

Male.-Primaries pale semihyaline fawn-colour; the costal margin, apex, and outer margin broadly black; a marginal row of fine rather large white spots extends from the apex to the anal angle: secondaries pale semihyaline fawn-colour, with the costal margin, apex, and outer margin black, and a row of white spots extends from the apex partly round the outer margin. The head, antennæ, thorax, and abdomen black; tegulæ black, with a white dot at the base; the underside of the abdomen fawn-colour; the legs black.

Expanse $2 \frac{1}{2}$ inches.

Hab. Colombia (Mus. Druce).

\section{Fam. Limacodidæ.}

Miresa sobrina, sp. n.

Male.-Primaries dark brown, crossed from the costal to the inner margin by two darker brown lines - the first zigzag, 
close to the base, the second beyond the middle: secondaries pale brown, palest at the base. The head, antennæ, and thorax dark brown; abdomen reddish brown, the anal tuft dark brown.

Expanse $1 \frac{1}{2}$ inch.

Hab. New Caledonia (Mus. Druce).

\section{Miresa alma, sp. n.}

Male.-Primaries and secondaries uniformly creamy white, shaded with yellowish brown along the inner margins of the secondaries. The head, antennæ, and thorax creamy white; abdomen black, banded with yellow; the legs dark brown.

Expanse $1 \frac{3}{4}$ inch.

Hab. New Caledonia (Mus. Druce).

XXXIII.-Note on the Specific Name of the Saccammina of the Carboniferous Limestone. By Frederick Chapman, A.L.S., F.R.M.S.

In the course of some investigations amongst Microzoa from the Carboniferous Limestone of Ireland I have met with the well-known Carboniferous foraminifer Saccammina in some abundance.

So far as I was aware S. Carteri, Brady, had not been definitely recorded (under that name) from the Irish limestones, excepting a general remark which Dr. H. B. Brady made in his report on the Foraminifera of the "Challenger' Expedition in 1854 *

In $1849 \dagger$, however, McCoy had recorded certain foraminifera from the Carboniferous Limestone of Ireland, to which he gave the name of "Nodosaria fusulinaformis." These specimens were described, but not figured, and up to the present appear to have been regarded as too ill-defined for the name to be retained; and, moreover, the name Saccammina Carteri had been fully established before McCoy's species had been, as it were, rediscovered.

The evidence for Nodosaria fusuliniformis of McCoy has been therefore carefully examined, and by the present note I think it will be seen to be identical with Brady's Saccammina Carteri.

* Zoology, vol, ix. p. 253.

† "On some new Genera and Species of Palæozoic Corals and Foraminifera," Ann. \& Mag. Nat. Hist. ser. 2, vol. iii. pp. 131, 132. 


\section{$2 \mathrm{BHL}$ Biodiversity Heritage Library}

Druce, Herbert. 1898. "XXXII.-Descriptions of some new species of Heterocera." The Annals and magazine of natural history; zoology, botany, and geology 1, 207-215. https://doi.org/10.1080/00222939808677955.

View This Item Online: https://www.biodiversitylibrary.org/item/63770

DOI: https://doi.org/10.1080/00222939808677955

Permalink: https://www.biodiversitylibrary.org/partpdf/60056

\section{Holding Institution}

University of Toronto - Gerstein Science Information Centre

\section{Sponsored by}

University of Toronto

\section{Copyright \& Reuse}

Copyright Status: NOT_IN_COPYRIGHT

This document was created from content at the Biodiversity Heritage Library, the world's largest open access digital library for biodiversity literature and archives. Visit BHL at https://www.biodiversitylibrary.org. 